Chapman University

Chapman University Digital Commons

Pharmacy Faculty Articles and Research

School of Pharmacy

6-23-2017

Efficient Synthesis of CN2097 Using In Situ Activation of Sulfhydryl Group

Shaban Darwish

Keykavous Parang

John Marshall

Dennis J. Goebel

Rakesh Tiwari

Follow this and additional works at: http://digitalcommons.chapman.edu/pharmacy_articles

Part of the Medical Neurobiology Commons, Medicinal and Pharmaceutical Chemistry

Commons, Neurology Commons, Other Pharmacy and Pharmaceutical Sciences Commons,

Pharmaceutics and Drug Design Commons, and the Therapeutics Commons 


\section{Efficient Synthesis of CN2097 Using In Situ Activation of Sulfhydryl Group}

\section{Comments}

NOTICE: this is the author's version of a work that was accepted for publication in Tetrahedron Letters. Changes resulting from the publishing process, such as peer review, editing, corrections, structural formatting, and other quality control mechanisms may not be reflected in this document. Changes may have been made to this work since it was submitted for publication. A definitive version was subsequently published in Tetrahedron Letters, volume 31, issue 2, in 2017. DOI:10.1016/j.tetlet.2017.06.066

The Creative Commons license below applies only to this version of the article.

\section{Creative Commons License}

\section{(c) 1 (1) 9}

This work is licensed under a Creative Commons Attribution-Noncommercial-No Derivative Works 4.0 License.

\section{Copyright}

Elsevier 


\section{Accepted Manuscript}

Efficient synthesis of CN2097 using in situ activation of sulfhydryl group

Shaban Darwish, Keykavous Parang, John Marshall, Dennis J. Goebel, Rakesh

Tiwari

PII:

S0040-4039(17)30804-3

DOI:

http://dx.doi.org/10.1016/j.tetlet.2017.06.066

Reference:

TETL 49058

To appear in:

Tetrahedron Letters

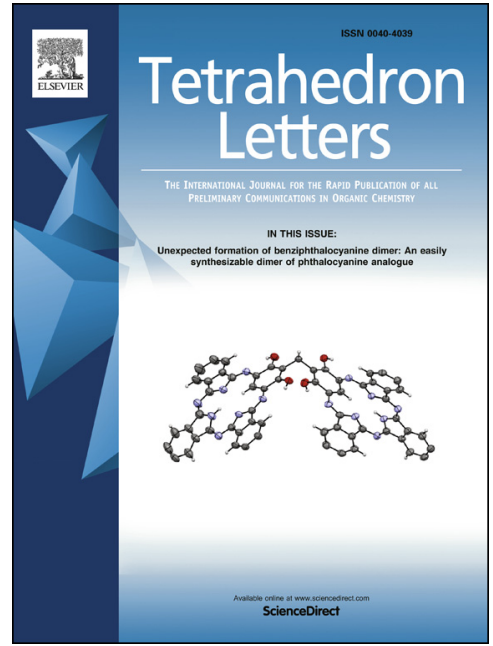

Received Date: $\quad 26$ May 2017

Revised Date: $\quad 19$ June 2017

Accepted Date: $\quad 22$ June 2017

Please cite this article as: Darwish, S., Parang, K., Marshall, J., Goebel, D.J., Tiwari, R., Efficient synthesis of CN2097 using in situ activation of sulfhydryl group, Tetrahedron Letters (2017), doi: http://dx.doi.org/10.1016/ j.tetlet.2017.06.066

This is a PDF file of an unedited manuscript that has been accepted for publication. As a service to our customers we are providing this early version of the manuscript. The manuscript will undergo copyediting, typesetting, and review of the resulting proof before it is published in its final form. Please note that during the production process errors may be discovered which could affect the content, and all legal disclaimers that apply to the journal pertain. 


\section{Graphical Abstract}

To create your abstract, type over the instructions in the template box below.

Fonts or abstract dimensions should not be changed or altered.

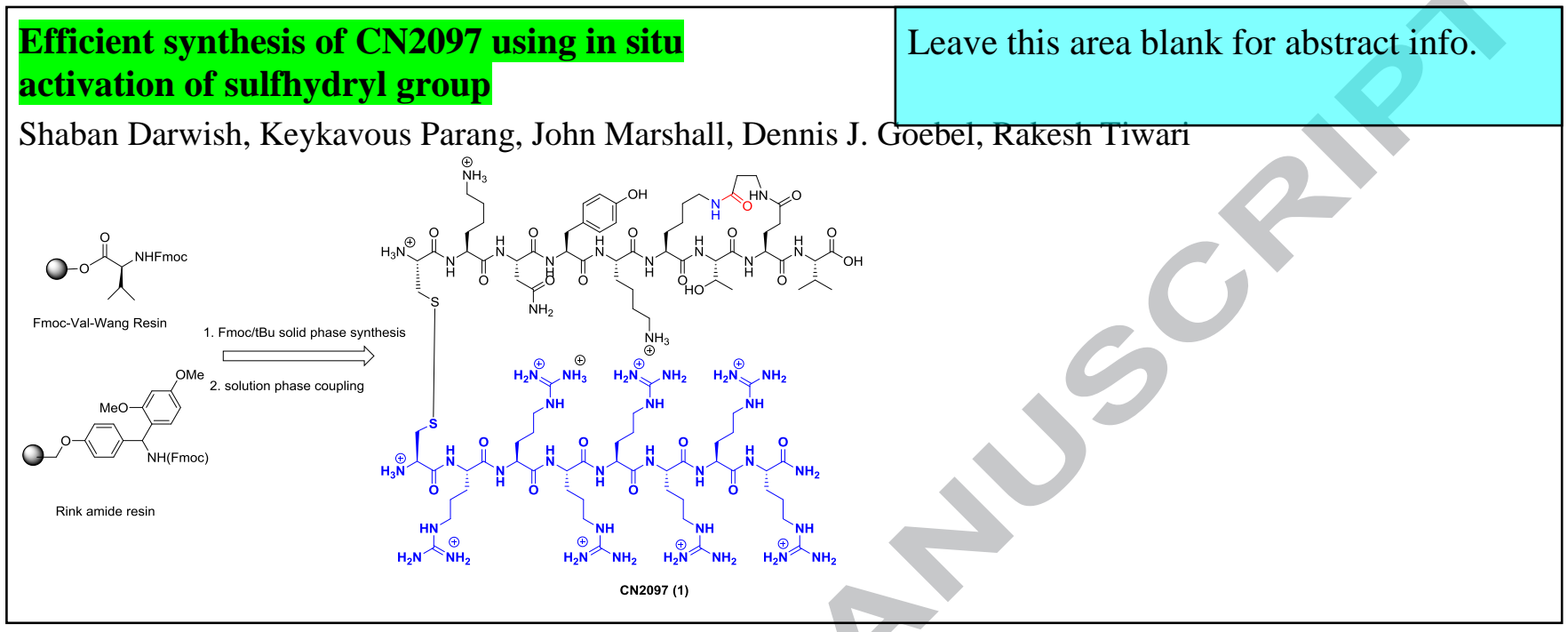




\title{
Efficient synthesis of CN2097 using in situ activation of sulfhydryl group
}

\author{
Shaban Darwish ${ }^{\mathrm{a}, \mathrm{d}}$, Keykavous Parang ${ }^{\mathrm{a}}$, John Marshall ${ }^{\mathrm{b}}$, Dennis J. Goebel ${ }^{\mathrm{c}}$, and Rakesh Tiwari ${ }^{\mathrm{a}}{ }$ * \\ ${ }^{a}$ Center for Targeted Drug Delivery, Department of Biomedical and Pharmaceutical Sciences, Chapman University School of Pharmacy, Harry and Diane \\ Rinker Health Science Campus, Irvine, California 92618, USA \\ ${ }^{b}$ Department of Molecular Pharmacology, Physiology, and Biotechnology, Brown University, Providence, RI, USA. \\ ${ }^{c}$ Department of Anatomy and Cell Biology, Wayne State University, Detroit, Michigan, USA \\ ${ }^{d}$ Organometallic and Organometalloid Chemistry Department, National Research Centre, El Bohouth st., Dokki, Giza, Egypt
}

\section{ARTICLE INFO}

\section{ABSTRACT}

\section{Article history:}

Received

Received in revised form

Accepted

Available online

Keywords:

CN2097

Disulfide

Fmoc/tBu,

Polyarginine

PDZ domain

Solid-phase chemistry
CN2097 ( R $\left._{7} \mathrm{Cs}-\mathrm{sCYK}[\mathrm{KTE}(\beta-\mathrm{Ala})] \mathrm{V}\right)$ is a rationally designed peptidomimetic that shows effectiveness in preclinical models for the treatment of neurological disorders, such as Angelman syndrome, traumatic brain injury (TBI) and stroke. Because of its therapeutic activity for the treatment of human CNS disorders, there was an urgent need to develop an efficient strategy for large-scale synthesis of CN2097. The synthesis of CN2097 was accomplished using Fmoc/tBu solid phase chemistry in multiple steps. Two different peptide fragments (activated polyarginine peptide Npys-sCR $\mathrm{S}_{7}$ and $\left.\mathrm{CYK}[\mathrm{KTE}(\beta-\mathrm{Ala})] \mathrm{V}\right)$ were synthesized, followed by solution phase coupling in water. Activation of the polyarginine $\left(\mathrm{CR}_{7}\right)$ was achieved in situ during cleavage of protected peptide $\left(\mathrm{C}(\mathrm{Trt}) \mathrm{R}(\mathrm{Pbf})_{7}\right)$ from the Rink amide resin using 5 equiv. of 2,2-dithopyridine in TFA:TIS: $\mathrm{H}_{2} \mathrm{O}(95: 2.5: 2.5, \mathrm{v} / \mathrm{v} / \mathrm{v})$ for $4 \mathrm{~h}$. The disulfide coupling was efficient which provided a $60 \%$ yield.

2017 Elsevier Ltd. All rights reserved.

\section{Introduction}

Postsynaptic density protein-95 (PSD-95), Discs-large, and zonula occludens-1 (PDZ) domains are 90 amino acid residue modular protein interaction domains found in scaffolding and adaptor proteins. ${ }^{1}$ PSD-95, which consists of three PDZ domains (PDZ1-3), is an abundant scaffold protein at excitatory synapses. The PDZ domains of PSD-95 bind to membrane receptors and ion channels via a C-terminal binding sequence, tSXV., 3 The PDZ domains of PSD-95 have been targets for the development of compounds for therapeutic application in ischemic brain injury, ${ }^{4-8}$ psycho-stimulant addiction, ${ }^{9}$ and Angelman syndrome. ${ }^{10}$ For example, the engineered peptide IETAV, containing the backbone of the five $C$-terminal amino acids of GluN2B, was shown to be a more potent inhibitor to the PDZ1 and PDZ2 domains of PSD95, than the native peptide. ${ }^{11}$ Similarly, a nine amino acid peptide from the CRIPT protein, which binds to the PDZ3 domain of PSD-95 ${ }^{12}$, was modified to develop a more efficient inhibitor. ${ }^{13}$ In addition to PSD-95, other PDZ domainassociated proteins have also been found to be important therapeutic drug targets, including syntenin in metastatic breast cancer, ${ }^{14}$ parkin in Parkinson's diseases, ${ }^{15}$ and E6 protein in oncogenic human papillomavirus. ${ }^{16,17}$

More recently a rationally designed peptidomimetic (designated CN2097) consisting of a polyarginine disulfidelinked cyclic PDZ binding motif through a lactam ring and $\beta$ alanine linker; $\left(\mathrm{R}_{7} \mathrm{Cs}-\mathrm{sCYK}[\mathrm{KTE}(\beta-\mathrm{Ala})] \mathrm{V}\right)$ was generated. The cyclic PDZ binding motif was designed based on last 5 residues of $C$-terminus of CRIPT scaffolding protein as found in the x-ray analysis of PDZ3 complex with CRIPT. ${ }^{12}$ These residues were modified to improve bonding interaction using beta-alanine. Polyarginine was added to improve cell-permeability. In preclinical animal studies, CN2097 was found to be effective in the treatment of Angelman syndrome, ${ }^{10} \mathrm{TBI}^{18}$, and neuroprotective in an excitotoxicity animal model that mimics a stroke. ${ }^{19}$ One of the major drawbacks in proceeding to preclinical trial studies is that the reported methodology for the synthesis of CN2097, based on solid phase and microwave chemistry, provides a low yield $(\sim 5 \%)^{20}$ during conjugation of polyarginine and cyclic PDZ peptide to form a disulfide bond. The synthesis consists of an activated cysteine on solid-phase that requires a large amount of cyclic-peptide for disulfide coupling on the resin. This, and the greater potential for denaturation of the peptide and/or inducing a change in the secondary structure under

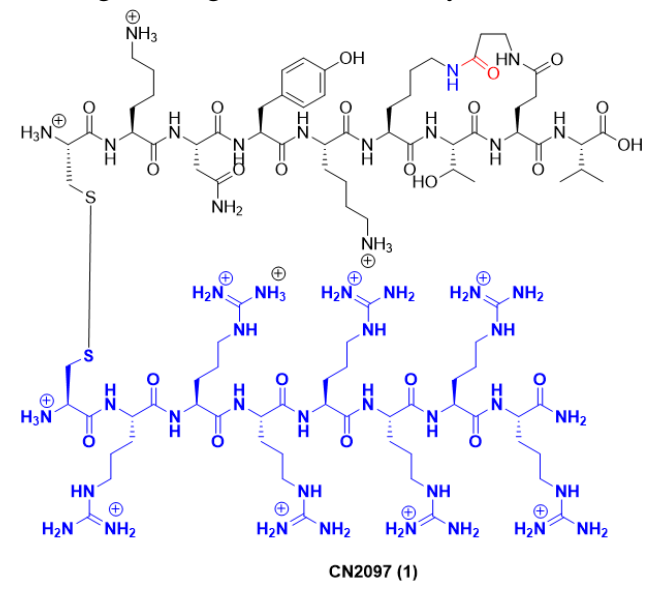


Figure 1. Chemical structure of CN2097 (1).

microwave heating during synthesis make scaling up the process impractical. ${ }^{20}$ Therefore, an efficient methodology for the synthesis of CN2097 is urgently required for generating a large amount of compound for the clinical studies. Herein, we report an efficient and novel synthesis of CN2097 in a higher scale.

\section{Results and discussion}

CN2097 consists of a PDZ macrocyclic peptide and polyarginine peptide that are linked by a disulfide linkage resulting from each peptides $N$-terminal cysteine residue. The individual peptides were synthesized independently and then coupled in the solution phase to produce a faster and more efficient coupling and for large-scale synthesis. Standard Fmocbased methodology was used to synthesize each peptide.

The synthesis of a macrocycle targeting the PDZ domain of PSD-95 was previously reported ${ }^{13}$ without a $N$ terminal cysteine residue. The peptide, $\mathrm{K}_{1} \mathrm{~N}_{2} \mathrm{Y}_{3} \mathrm{~K}_{4} \mathrm{~K}_{5} \mathrm{~T}_{6} \mathrm{E}_{7} \mathrm{~V}_{8}$, was based on the C-terminal residues of CRIPT and was synthesized using Fmoc/tBu solid-phase chemistry. A cysteine residue was added at the $\mathrm{N}$-terminus for disulfide coupling. The peptide sequence was assembled on the Fmoc-Val-Wang resin (2) using Fmoc-Glu(Ophipr)-OH, Fmoc-Thr(tBu), Dde-Lys(Fmoc)-OH, and Fmoc- $\beta$-Ala-OH with coupling and deprotection cycles with 2-(1H-benzotriazol-1-yl)-1,1,3,3-tetramethyluronium

hexafluorophosphate (HBTU)/ N,N-diisopropylethylamine (DIPEA) and piperidine in $N, N$-dimethylformamide (DMF) $(20 \%$ $\mathrm{v} / \mathrm{v})$, respectively. After the synthesis of the linear protected peptide on the solid phase (Dde-K( $\beta$-Ala-NHFmoc)- $\mathrm{T}(\mathrm{tBu})$ E(OPhipr)-V-Wang resin, 3) was confirmed using ESI mass after cleavage of small amount of resin, the Phipr group from glutamic acid was selectively deprotected using $2.5 \%(\mathrm{v} / \mathrm{v}) \mathrm{TFA}$ in $(5 \%$ $\mathrm{v} / \mathrm{v}$ ethanedithiol (EDT) in dichloromethane (DCM)) for 10 minutes 3 times, which showed incomplete removal of Phipr group. Therefore, the TFA concentration was increased to $5 \%$ in the EDT $(5 \%)$ in DCM. Subsequently, the Fmoc group from $\beta$ alanine was removed using $20 \%$ piperidine in DMF followed by washing. The resin appeared to aggregate as observed during washing, which may be due to electrostatic charges between $\mathrm{COOH}$ and $\mathrm{NH}_{2}$ group as depicted in Scheme 1 for compound 4. On resin cyclization was carried out using PyBOP/HOBt (3 equiv.), DIPEA (6 equiv.) under nitrogen and using DMSO:NMP $(1: 4 \mathrm{v} / \mathrm{v})$ for $4 \mathrm{~h}$ and found to be complete as monitored by electrospray ionization mass spectrometer which showed a peak of 693.4215 corresponding to $[\mathrm{M}+\mathrm{H}]^{+}$for cyclic compound $\mathbf{5}$. The resin was washed and used for elongation of peptide chain by deprotection of Dde group. The peptidyl-resin was treated with hydrazine in DMF (2\% v/v) for 15 min followed by washing and coupling subsequent Fmoc-protected amino acids, FmocLys(Boc)-OH, Fmoc-Tyr(OtBu)-OH, Fmoc-Asn(Trt)-OH, FmocLys(Boc)-OH and Boc-Cys(Trt)-OH, respectively, to generate 6. The deprotection of the side chains, final cleavage from the solid support using cleavage cocktail $\mathrm{R}$ (trifluoroacetic acid (TFA)/thioanisole/1,2-ethanedithiol/ anisole 90:5:3:2 v/v/v/v, 2 h), purification with HPLC, and lyophilization afforded macrocyclic peptide 7 containing a cysteine residue. The chemical structure of peptide 7 was confirmed using a highresolution matrix-assisted laser desorption/ionization (MALDI) spectrometer.

In a separate synthesis, the polyarginine-cysteine peptide $\mathbf{1 0}$ was synthesized using Fmoc/tBu solid-phase chemistry and Rink amide resin 8. Fmoc-Arg(Pbf)-OH was coupled after deprotection of Fmoc group from the resin. Six more arginine residues were coupled under similar conditions followed by

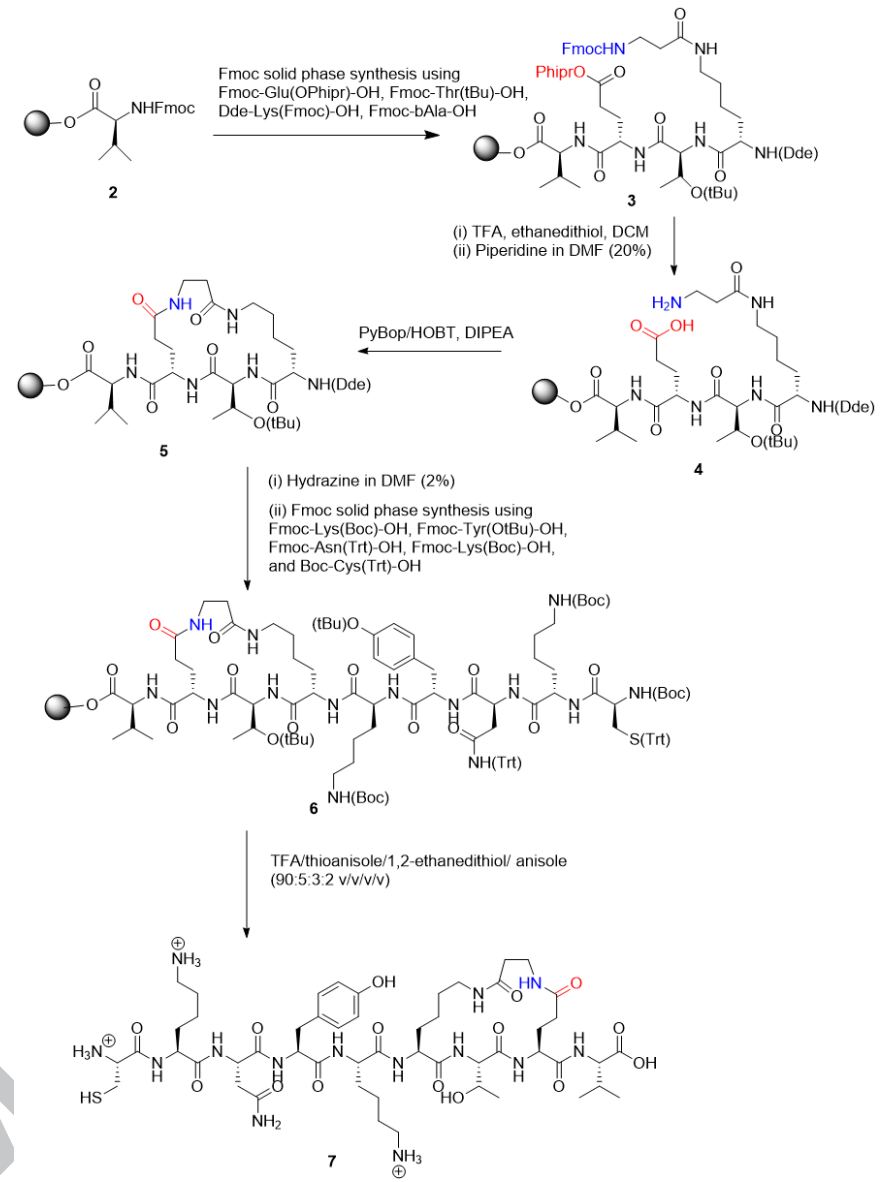

Scheme 1. Synthesis of macrocyclic PDZ peptide 7.
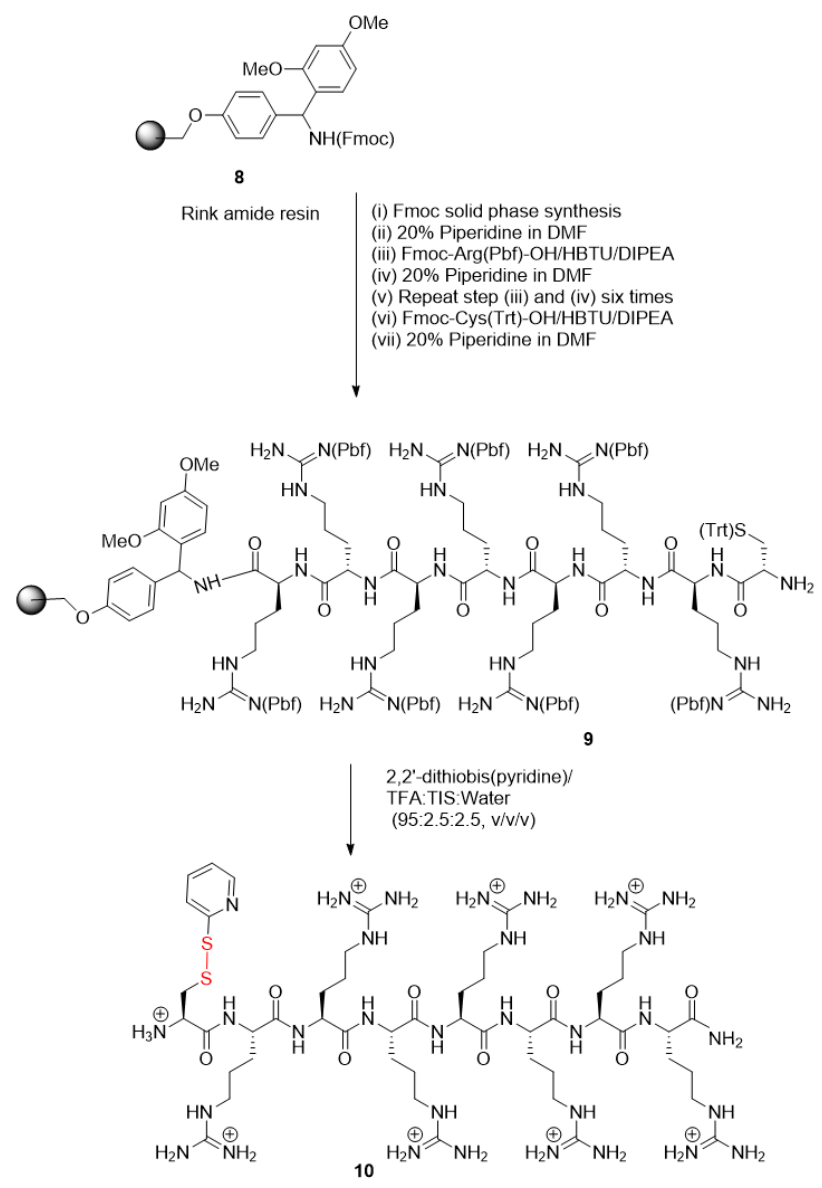

Scheme 2. Synthesis of activated polyarginine peptide $\mathbf{1 0}$. 
addition of a cysteine residue using Fmoc-Cys(Trt)-OH. Fmoc group at the $N$-terminal was deprotected to afford peptidyl resin 9. Cysteine was added at the $N$-terminus for disulfide coupling to the macrocyclic peptide. The cleavage of a small amount of the resin confirmed the formation of linear $\mathrm{CR}_{7}$ peptide in the MALDI spectrometer. The disulfide coupling was facilitated by adding the activated cysteine in the polyarginine chain rather than macrocyclic peptide 7 since the linear peptide was easily

synthesized as compared to macrocyclic peptide. The use of Boc$\mathrm{Cys}(\mathrm{Npys})-\mathrm{OH}$ in $\mathrm{CR}_{7}$ peptide to get activated sulfhydryl provided a very small amount of conjugated peptide CN2097 (around 5\% yield) in our attempt. ${ }^{20}$ Thus, we activated sulfhydryl group in the peptide using 2,2'-dithiodipyridine (DTP). The activation of sulfhydryl group failed under normal solution phase conditions using DTP and polyarginine peptide with the acidic condition. Therefore, we followed in situ activation of sulfhydryl group during cleavage of the peptide from the resin and removal of the protecting group. The final deprotection and cleavage of the polyarginine peptide from the resin using the 5 equivalent of 2,2'-dithiodipyridine in cleavage cocktail (water/triisopropylsilane/TFA (2.5:2.5:95, v/v/v) for $4 \mathrm{~h}$ afforded the activated cysteine generated in situ within the polyarginine peptide $\mathbf{1 0}$ that was purified by HPLC and lyophilized. It is worthwhile to note that $4 \mathrm{~h}$ cleavage time removed most of the $\mathrm{Pbf}$ protecting groups from the side chain of arginine and provided activated pyridyl-s-sCR 7 peptide. However, cleavage time longer than $4 \mathrm{~h}$ resulted in the loss of s-pyridyl group, leaving only the $\mathrm{CR}_{7}$ peptide.

$7+10$

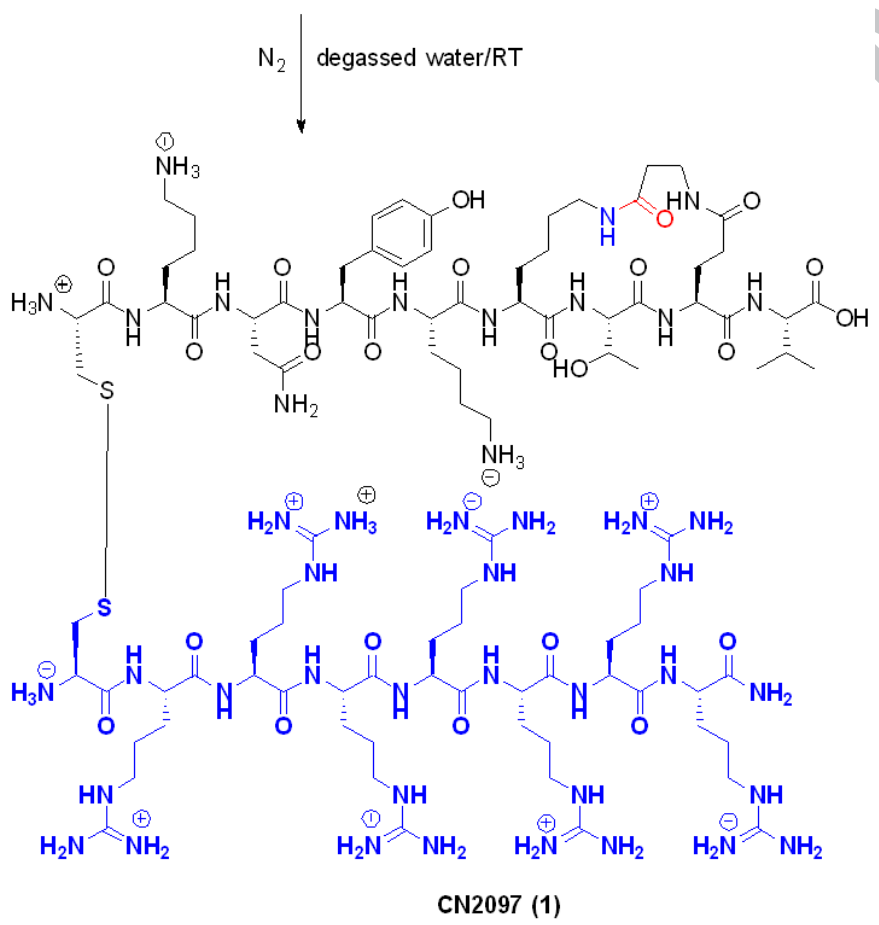

Scheme 3. Synthesis of CN2097(1).

The final coupling of the two synthesized peptides (PDZ macrocyclic peptide 7 and polyarginine peptide 10) to form disulfide bond was carried out in solution phase using an equimolar ratio of macrocyclic peptide 7 and the polyarginine peptide 10 under a nitrogen atmosphere with degassed water for $18 \mathrm{~h}^{21}$ (Scheme 3) MALDI-TOF analysis of the reaction after $2 \mathrm{~h}$ showed the formation of the product. After final HPLC purification and lyophilization, CN2097 (1) containing the disulfide bond was obtained (Figure 1). The conjugation reaction proceeds with high yield $(>60 \%$ yield after conjugation of two

peptides and HPLC purification). We synthesized $250 \mathrm{mg}$ of CN2097 (1) using in situ sulfhydryl activation of polyarginine peptide (10) and obtained compound 1 in overall $25 \%$ yield after multiple HPLC purification. The chemical structure of CN2097 was confirmed using a high-resolution time-of-flight electrospray mass spectrometer.

\section{Conclusions}

We have developed an efficient method for the large-scale synthesis of CN2097 required for clinical studies. After solidphase synthesis of the macrocyclic and polyarginine peptides, a solution phase condition with an equimolar ratio of macrocyclic and polyarginine peptide was used to synthesize CN2097 in the final step. The in situ activation of cysteine in the polyarginine peptide provides the activated cysteine for disulfide conjugation. Our methodology provides higher yield $(>60 \%)$ and high purity $98 \%$ of the synthesized CN2097.

\section{Acknowledgments}

The authors greatly acknowledge financial support for this research from Chapman University School of Pharmacy and partial support from Alexion Pharmaceuticals, Inc. Funding for this work also came from the NINDS R01 5R01NS094440 and R21 MH104252-02 (J.M).

\section{References}

1

2

3

4
Kennedy MB. Trends Biochem Sci 1995, 20, 350. Doyle DA, Lee A, Lewis J, Kim E, Sheng M, MacKinnon R. Cell 1996, 85, 1067-1076. Jemth P, Gianni S. Biochemistry 2007, 46, 8701-8708. Bach A, Clausen BH, Moller M, Vestergaard B, Chi CN, Round A, Sorensen PL, Nissen KB, Kastrup JS, Gajhede M, Jemth P, Kristensen AS, Lundstrom P, Lambertsen KL, Stromgaard K. Proc Natl Acad Sci USA 2012, 109, 3317-3322.

Aarts M, Liu Y, Liu L, Besshoh S, Arundine M, Gurd JW, Wang YT, Salter MW, Tymianski M. Science 2002, 298, 846-850.

Tymianski M. Nat Neurosci 2011, 14, 1369-1373. Chi CN, Bach A, Stromgaard K, Gianni S, Jemth P. Biofactors 2012, 38, 338-348.

Hill MD, Martin RH, Mikulis D, Wong JH, Silver FL, Terbrugge KG, Milot G, Clark WM, Macdonald RL, Kelly ME, Boulton M, Fleetwood I, McDougall C, Gunnarsson T, Chow M, Lum C, Dodd R, Poublanc J, Krings T, Demchuk AM, Goyal M, Anderson R, Bishop J, Garman D, Tymianski M, investigators Et. Lancet Neurol 2012, 11, 942-950.

Roche KW. Trends Neurosci 2004, 27, 699-700.

Cao C, Rioult-Pedotti MS, Migani P, Yu CJ, Tiwari R, Parang K, Spaller MR, Goebel DJ, Marshall J. PLoS Biol 2013, 11, e1001478.

Bach A, Chi CN, Olsen TB, Pedersen SW, Roder MU, Pang GF, Clausen RP, Jemth P, Stromgaard K. J Med Chem 2008, 51, 6450-6459.

Niethammer M, Valtschanoff JG, Kapoor TM, Allison DW, Weinberg RJ, Craig AM, Sheng M. Neuron 1998, 20, 693-707.

Li T, Saro D, Spaller MR. Bioorg Med Chem Lett 2004, 14, 1385-1388

Koo TH, Lee JJ, Kim EM, Kim KW, Kim HD, Lee JH. Oncogene 2002, 21, 4080-4088. 
15 Dev KK, van der Putten H, Sommer B, Rovelli G.

Neuropharmacology 2003, 45, 1-13.

16 Kiyono T, Hiraiwa A, Fujita M, Hayashi Y, Akiyama T, Ishibashi M. Proc Natl Acad Sci USA 1997, 94, 1161211616.

17 Nguyen ML, Nguyen MM, Lee D, Griep AE, Lambert PF. J Virol 2003, 77, 6957-6964.

$18 \quad$ Marshall J, et al. (Submitted) 2017.

19 Marshall J, Wong KY, Rupasinghe CN, Tiwari R, Zhao X, Berberoglu ED, Sinkler C, Liu J, Lee I, Parang K, Spaller MR, Huttemann M, Goebel DJ. J Biol Chem 2015, 290, 22030-22048.

20 Marshall JB, RI, US, Mallon, Andrew (Lincoln, RI, US) In Long term potentiation with cyclic-GluR6 analogs; Brown University (Providence, RI, US), United States, 2014, US Patent \#US 20120149646 A1.

21. Procedure for the synthesis of CN2097 (1) by solutionphase coupling reactions of 7 and 10: The final disulfide coupling was performed by using polyarginine peptide $(10,20.0 \mathrm{mg}, 15.12 \mathrm{mmol})$ dissolved in $2 \mathrm{~mL}$ of degassed water and addition of peptide $7(17.6 \mathrm{mg}$, 15.12) at room temperature. After addition of cyclic peptide 7, the color of the reaction was turned to light yellow. After stirring for $18 \mathrm{~h}$, the reaction was diluted with ethyl acetate $(2 \mathrm{~mL})$. The aqueous phase was separated and extracted with ethyl acetate $(3 \times 5 \mathrm{~mL})$. The aqueous phase was lyophilized and the residue was purified by reverse phase HPLC (C18 column using 1$20 \%$ acetonitrile gradient over $30 \mathrm{~min}$ ) to afford CN2097 (1) in >60\% overall yield (Figure 1). The chemical structure of $\mathrm{CN} 2097$ was determined using a high-resolution MALDI-TOF (m/z) $\mathrm{C}_{96} \mathrm{H}_{174} \mathrm{~N}_{44} \mathrm{O}_{23} \mathrm{~S}_{2}$ : calcd. 2375.3240 found $1215.0348[\mathrm{M}+\mathrm{H}-\text { cyclic }]^{+}$, $1166.9063\left[\mathrm{M}+2 \mathrm{H}-\mathrm{CR}_{7}\right]^{+}, 2378.5848[\mathrm{M}+3 \mathrm{H}]^{+}$.

\section{Supplementary Material}

Supplementary data associated with this article can be found, in the online version, at http://dx.doi.org/. 


\section{Highlight}

- An efficient synthesis of CN2097 was

developed to overcome low yield and purity issue.

- CN2097 is under preclinical studies and require a large amount of compound.

- Insitu sulfhydryl activation and solution phase coupling of both peptides provided good yield and purity. 